\title{
Postural change and intraocular pressure in glaucomatous eyes
}

\author{
U. W. WÜTHRICH \\ Switzerland
}

Several authors (Anderson and Grant, I973; Galin, McIvor, and Magruder, 1963; HetlandEriksen, 1966; Kriegelstein and Langham, 1975a; Roberts and Rogers, 1964; Tarkkanen and Leikola, 1967) have reported that in normal subjects and in glaucomatous patients the intraocular pressure (IOP) in the supine position is about $2-5 \mathrm{mmHg}$ higher than in the seated position. The measurements were carried out using various types of tonometers.

The object of the present study was to investigate the postural response of intraocular pressure, using the pneumatonograph mod. 40* (PTG), the Perkins hand-held tonometer, and the Goldmann tonometer. The PTG gives an instantaneous and continuous record of the intraocular pressure. It was described by Langham and McCarthy (r968), and the results of clinical trials were reported by Geib, Kriegelstein, and Waller (1974); it would seem to be particularly suitable for recording the IOP in various postures. In this study the Goldmann applanation tonometer attached to a HaagStreit slit lamp mod. 900 was used for the sitting position, and the Perkins hand-held tonometer (Perkins, 1965) and the PTG were used for the seated and supine positions. Good agreement between readings of the Perkins tonometer and the Goldmann tonometer has been reported (Dunn and Brubaker, 1973; Kriegelstein and Waller, 1975; Flament, 1969; Whitty, 1969; Wallace and Lovell, 1968).

\section{Material and methods}

The PTG was used as suggested by Langham and McCarthy (1968), but only in the $\times$ I gain code. Pressure calibrations were performed in the vertical and horizontal positions, using a human cornea clamped in a Perspex chamber which was filled with water and connected to a manometer; the stopcock was left open. The sensor was clamped in a stand and the tip of the sensor was brought mechanically into contact with the *Supplied by Firma Digilab, Cambridge, Mass. USA

cornea, so that a reproducible reading could be obtained.

The clinical tests were carried out in the Glaucoma Clinic at the Institute of Ophthalmology in London on 53 outpatients of both sexes who had primary glaucomas of various types. Some eyes were receiving medical treatment and some had had drainage surgery. The three tonometers were used in sequence on patients in the seated position, first on the right eye, then on the left. Tight clothes were loosened before the measurements were taken and each patient was asked to lie flat without a pillow for measurements in the supine position using the Perkins tonometer and the PTG. The eyes were anaesthetized with a mixture of oxybuprocaine and fluorescein (Fenton, 1965). All measurements were carried out by the same investigator and repeated three times on each eye and with each instrument 3-5 min after changing position.

\section{Results}

\section{CALIBRATION}

With the Perspex chamber arranged for horizontal application of the tonometer the calibration was linear from 5 to $30 \mathrm{mmHg}$ and the readings were identical with those of the manometer (Fig. I). It was found possible to obtain higher readings by increasing the pressure on the sensor against the

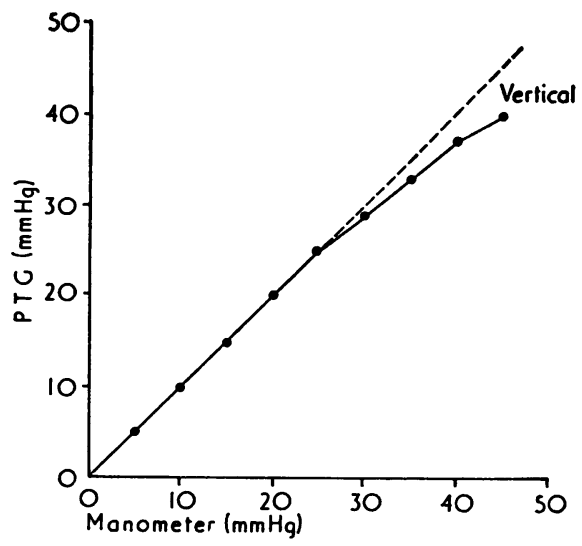

FIG. I Calibration of PTG for horizontal application of sensor. (Corresponding to vertical position of patient) 


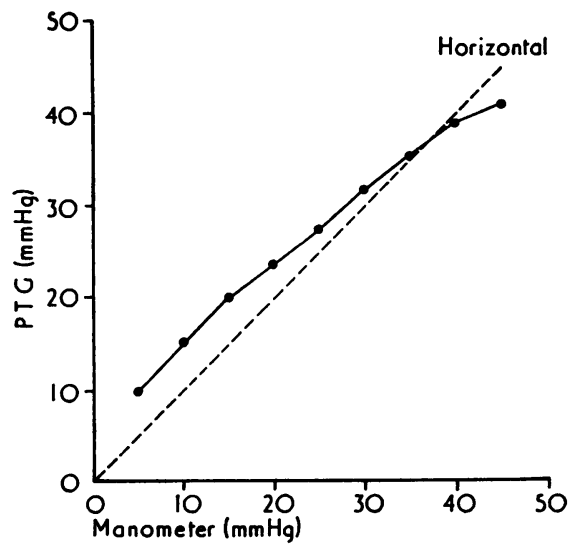

FIG. 2 Calibration of PTG for vertical application of sensor. (Corresponding to horizontal position of patient)

cornea without any alteration to the quality of the sound signal, which is said to act as a control for false readings. The recordings with vertical application of the tonometer showed higher readings (up to $30 \mathrm{mmHg}$ ), while above $35 \mathrm{mmHg}$ the readings were lower than those of the manometer (Fig. 2).

\section{CLINICAL TESTS}

The mean values of the intraocular pressure measurements in ro5 eyes are shown in Table I. No significant difference could be found between the Goldmann and the Perkins tonometric measurements in the seated position, Table II. Highly significant differences resulted, however, when the Perkins tonometric and the PTG readings in the seated and supine position were compared.

Fig. 3 shows the Perkins and Goldmann tonometric readings and Figs 4 and 5 show the Perkins tonometric and the PTG readings, plotted for different positions. Table III shows the frequency of discrepancies between the PTG and the Perkins tonometer readings in the present study. The discrepancy can be reduced if the PTG readings are corrected by $-4 \mathrm{mmHg}$ for the seated position and $-3 \mathrm{mmHg}$ for the supine.

\section{Discussion}

The significant increases in IOP on changing $\overparen{D}$ from the sitting to the supine position of $4.1 \mathrm{mmHg}$

Table I Mean readings and standard deviations of IOP in 105 glaucomatous eyes measured with Goldmann tonometer in seated position, and with Perkins tonometer and PTG in seated and supine position

\begin{tabular}{lll}
\hline Tonometer & \multicolumn{2}{l}{ Mean value $\pm S D(\mathrm{mmHg})$} \\
\cline { 2 - 3 } & \multicolumn{1}{c}{ Seated } & Supine \\
\cline { 3 - 3 } & & \\
\hline Goldmann & $20.42 \pm 5.01$ & - \\
Perkins & $20.20 \pm 5.01$ & $24.34 \pm 5.67$ \\
PTG & $24.34 \pm 4.96$ & $27.06 \pm 4.79$ \\
\hline
\end{tabular}

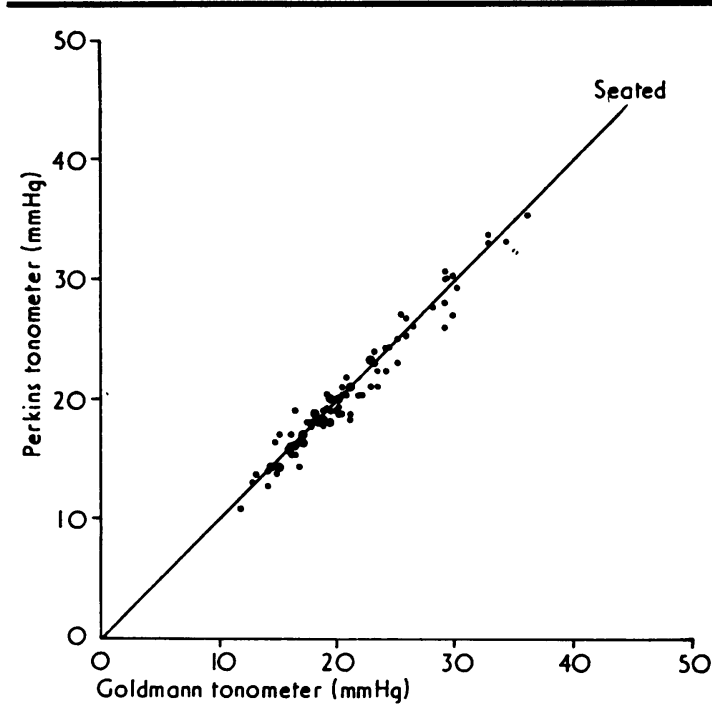

FIG. 3 Comparative IOP measurements with Goldmann and Perkins tonometers in series of 105 glaucomatous eyes in seated position

Table II Mean differences, significance, and correlation coefficients of IOP in 105 glaucomatous eyes using Goldmann tonometer in seated position, and Perkins tonometer and PTG in seated and supine position

\begin{tabular}{|c|c|c|c|c|}
\hline \multirow{2}{*}{ Tonometer } & \multicolumn{2}{|c|}{ Mean difference $\pm S D(m m H g)$} & \multirow{2}{*}{$\begin{array}{l}\text { Significance } \\
\text { of the mean } \\
\text { difference }\end{array}$} & \multirow{2}{*}{$\begin{array}{l}\text { Correlation } \\
\text { coefficient }\end{array}$} \\
\hline & Seated & Supine & & \\
\hline $\begin{array}{l}\text { Goldmann/Perkins } \\
\text { Goldmann/PTG } \\
\text { Perkins/PTG } \\
\text { Perkins/PTG }\end{array}$ & $\begin{array}{r}-0.22 \pm 0.94 \\
+3.93 \pm 2.30 \\
+4.14 \pm 2.11\end{array}$ & $+2 \cdot 74 \pm 2 \cdot 77$ & $\begin{array}{l}\text { Not significant } \\
P<0.0005 \\
P<0.0005 \\
P<0.0005\end{array}$ & $\begin{array}{l}0.978 \\
0.887 \\
0.901 \\
0.864\end{array}$ \\
\hline
\end{tabular}


Table III Differences in PTG and Perkins tonometric readings as found in this study compared with PTG readings corrected by $-4 \mathrm{mmHg}$ in seated and $-3 \mathrm{mmHg}$ in supine position

\begin{tabular}{|c|c|c|c|c|}
\hline \multirow{2}{*}{ Difference PTG-Perkins $T( \pm m m H g)$} & \multicolumn{2}{|c|}{ No. of readings } & \multicolumn{2}{|c|}{$P T G$ readings corrected by } \\
\hline & Seated & Supine & $\begin{array}{l}-4 m m H g \\
\text { Seated }\end{array}$ & $\begin{array}{l}-3 \mathrm{mmHg} \\
\text { Supine }\end{array}$ \\
\hline $\begin{array}{l}\text { Up to I } \\
2 \text { or } 3 \\
4 \text { or above }\end{array}$ & $\begin{array}{l}14 \\
25 \\
66\end{array}$ & $\begin{array}{l}33 \\
40 \\
32\end{array}$ & $\begin{array}{l}52 \\
43 \\
10\end{array}$ & $\begin{array}{l}48 \\
34 \\
23\end{array}$ \\
\hline
\end{tabular}

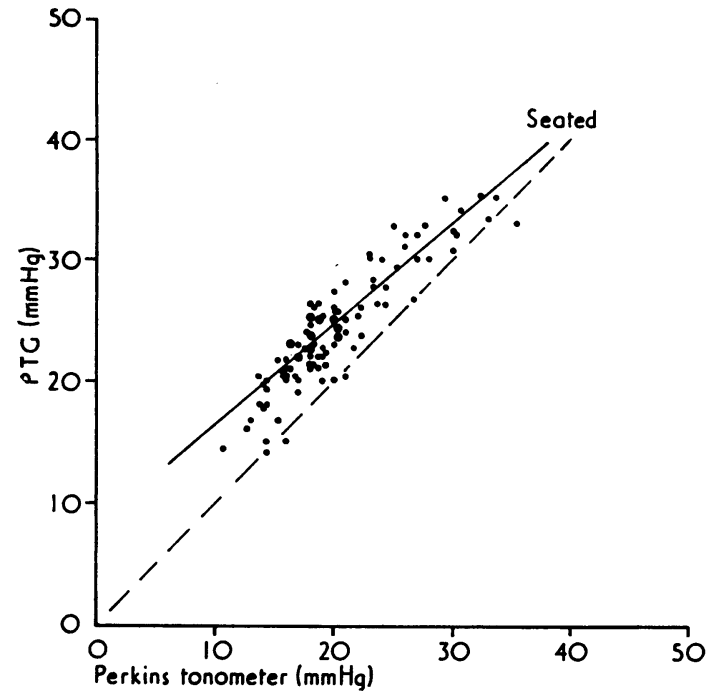

FIG. 4 Comparative IOP measurements with Perkins tonometer and PTG in series of 105 glaucomatous eyes in seated position

with the Perkins tonometer and $2.8 \mathrm{mmHg}$ with the PTG are comparable with the measurements of Geib and others (1974) and other workers.

The accuracy of the PTG is worth some discussion. The PTG showed a mean reading of 3.9 $\mathrm{mmHg}$ higher than that of the Goldmann tonometer and $4.1 \mathrm{mmHg}$ higher than the Perkins tonometer in the seated position; it was $2.6 \mathrm{mmHg}$ higher than the Perkins tonometer in the supine position. Geib and others (1974) found in their study that an average reading of the PTG was 2.9 $\mathrm{mmHg}$ higher than that of the Goldmann tonometer. Kriegelstein and Langham (1975b) subtracted $2 \mathrm{~mm}$ $\mathrm{Hg}$ from readings, when using the PTG in their work on low-tension glaucoma.

In the present study 63 per cent of PTG readings differed by $4 \mathrm{mmHg}$ or more when compared with the readings of the Perkins tonometer in the sitting position, the corresponding figure in the supine position being 30 per cent. Subtracting 4 $\mathrm{mmHg}$ from the PTG readings in the sitting position and $3 \mathrm{mmHg}$ in the supine position reduces ne discrepancy between the two methods. Such a correction does not alter the rather large scatter of PTG readings compared with the Goldmann or Perkins tonometer readings. In clinical practice accurate tonometry is important at the upper level of normal pressures, approximately $2 \mathrm{I} \mathrm{mmHg}$; at this level the PTG readings differed from the Goldmann reading by -3 to $+10 \mathrm{mmHg}$ in the sitting position and by -4 to $+12 \mathrm{mmHg}$ from the Perkins tonometer readings in the supine position.

It should be pointed out that the PTG used in this study was an early model, but the satisfactory calibration curves obtained on the isolated human cornea suggest that the instrument was working correctly. The discrepancies between PTG readings and those of other tonometers could have

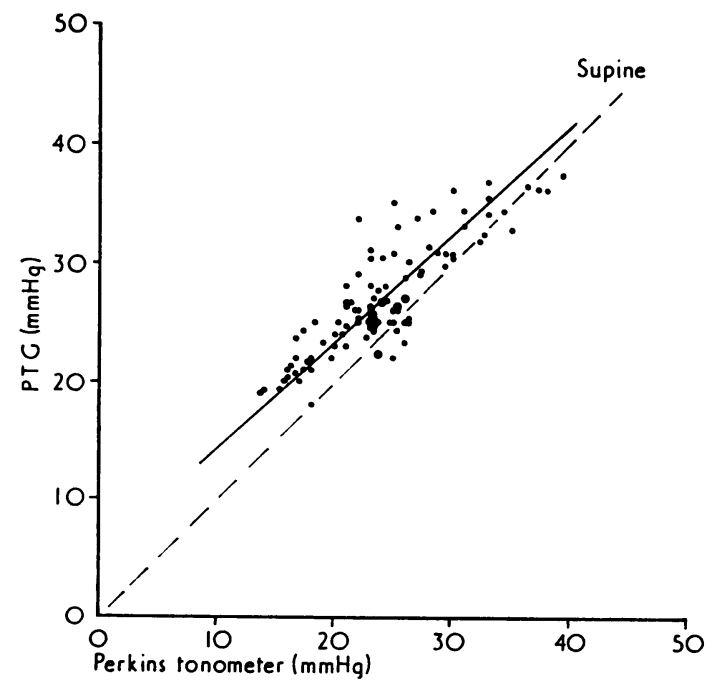

FIG. 5 Comparative IOP measurements with Perkins tonometer and PTG in series of 105 glaucomatous eyes in supine position 
resulted from variations in the position of the sensor on the cornea and the higher mean readings probably resulted from an indentation of the cornea causing an increase in IOP. A modified sensor with a pneumatic bearing to limit this effect has been described (Walker and Langham, 1975).

\section{Conclusions}

In glaucomatous eyes the IOP was found to be 3-4 $\mathrm{mmHg}$ higher in the supine position than in the seated position when the pressure was measured 3-5 min after the change in position. The accuracy of an early model of PTG mod. 40 did not seem to be entirely satisfactory.

I should like to express my gratitude to Professor E. S. Perkins and Dr J. Gloster for permitting me to perform this study and for their advice, to $\mathrm{Mr} \mathrm{B}$. Augier for the calculations, and to the staff of the Special Clinics and the Department of Experimental Ophthalmology for their kind help.

\section{References}

ANDERSON, D. R., and GRANT, W. M. (1973) Invest. Ophthal., 12, 204

DUNN, J. S., and BRUBAKER, R. F. (1973) Arch. Ophthal., 89, 149

Flament, P. M. J. (1969) Bull. Soc. Ophtal. Fr., 69, 640

FENTON, P. J. (1965) Brit. F. Ophthal., 49, 205

GALIN, M. A., MCIVOR, J. W., and MAGRUDER, G. B. (1963) Amer. F. Ophthal., 55, 720

GeIB, G., KRIEGelstein, G. K., and WAller, w. (1974) Klin. Mbl. Augenheilk., 164, 43 I

HETLAND-ERIKSEN, J. (1966) Acta. ophthal. (Kbh.), 44, 515

KRIEGELSTEIN, G. K., and LANGHAM, M. E. (1975a) Ophthalmologica (Basel), I71, I32

$$
\text { , - (1975b) Klin. Mbl. Augenheilk., 166, } 18
$$

and Waller, w. K. (1975) v. Graefes Arch. Ophthal., 194, I I

LANGHaM, K. E., and MCCARTHY, E. (1968) Arch. Ophthal., 79, 389

PERKINS, E. S. (1965) Brit. F. Ophthal., 49, 591

ROBERTS, W., and ROGERS, J. W. (1964) Amer. F. Ophthal., 57, I I I

TARKKANEN, A., and LEIKOLA, J. (1967) Acta. ophthal. (Kbh.), 45, 569

WALKER, R. E., and LANGHAM, M. E. (1975) Exp. Eye Res., 20, 167

WALlACE, J., and LOVELl, H. G. (1968) Brit. F. Ophthal., 52, 568

WHITTY, H. P. B. (1969) Brit. F. Ophthal., 53, 664 